\title{
Resenha: A confissão da leoa de Mia Couto
}

\section{Por Igor Fernando Xanthopulo Carmo ${ }^{1}$}

"Deus já foi mulher", assim se inicia o último romance de Mia Couto. Publicado no Brasil pela Companhia das Letras em 2012, A confissão da Leoa traz as inconfundíveis marcas literárias do escritor moçambicano. $\mathrm{O}$ abalo entre as fronteiras da ficção e da realidade, a fusão do discurso narrativo e da linguagem poética e o conflito entre o universo ancestral e a herança colonial continuam presentes na criação do autor. Inspirada numa experiência real, o mote da obra é o ataque de leões a uma pequena comunidade no norte de Moçambique. Entretanto, o episódio se desenvolve como pano de fundo para iluminar tanto questões existenciais, como a morte e a loucura, quanto impasses sociais e históricos, ao refletir a condição da mulher e as marcas deixadas pela colonização e guerra.

O escritor explica nas primeiras notas que o romance surge de sua experiência como biólogo:

\begin{abstract}
"Em 2008, a empresa em que trabalho enviou quinze jovens para atuarem como oficiais ambientais de campo durante a abertura de linhas de prospecção sísmica em cabo Delgado, no Norte de Moçambique. Na mesma altura e na mesma região, começaram a ocorrer ataques de leões a pessoas. Em poucas semanas, o número de ataques fatais atingiu mais de uma dezena. Esse número cresceu para vinte em cerca de quatro meses."
\end{abstract}

Inspirado neste caso, Mia Couto acrescenta que as personagens da trama foram baseadas em pessoas reais. Entre as personagens estão os dois protagonistas: Mariamar e Arcanjo Baleiro. Ambos são narradores-personagens, pois a obra se desenvolve a partir de seus escritos biográficos, apresentados de forma intercalada no romance. Os escritos da moça, intitulados versão de Mariamar, ainda que repletos de subjetividades, relatam os acontecimentos pela ótica local. A moça vive em Kulumani, aldeia onde se

\footnotetext{
${ }^{1}$ Aluno de Mestrado do Programa de Estudos Comparados de Literaturas de Língua Portuguesa da Universidade de São Paulo. E-mails para contato: igor.fernando.carmo@usp.br, igorxanthopulo@hotmail.com
} 
desenvolve a trama. De seu pertencimento à terra, resulta-se a intimidade com o espaço - o rio que cruza a vila, o mato, a aldeia - e com as tradições locais - a religiosidade, os costumes, a memória. Em contraposição, os escritos de Baleiro, diário do caçador, apresentam o olhar do viajante. O caçador de leões, proveniente da capital, lança mão de sua condição de estrangeiro para refletir sobre os insólitos episódios da aldeia.

$\mathrm{O}$ enredo se desenvolve num pequeno povoado no interior de Moçambique onde mulheres começam a ser devoradas por leões. Uma empresa que está na região contrata os serviços de Arcanjo Baleiro para matar os felinos que aterrorizam a comunidade isolada. Além do caçador, também é enviado para acompanhar a expedição um escritor de renome, Gustavo Regalo, que recebe a tarefa de reportar a caçada. Seguem também à pequena vila o administrador da província, Florindo Makwala, e sua esposa, Naftalinda. É importante ressaltar que o caçador Arcanjo Baleiro já estivera na aldeia dezesseis anos antes, ocasião em que salvara uma jovem de dezesseis anos de idade de um estupro. A jovem era Mariamar e, aparentemente, ambos se apaixonaram de forma recíproca. No entanto, o caçador parte da aldeia, deixando Mariamar sem qualquer notícia.

Já no tempo presente da narrativa, pró́bem a moça de sair em virtude do retorno de Baleiro à vila. Por essa razão, ela tenta fugir da aldeia, mas defronta-se com a temida fera às margens do rio Lidéia. Uma leoa fita profundamente os olhos de Mariamar que, desde então, passa a estar enclausurada em casa, relatando sua biografia nos escritos da versão de Mariamar. A paralisia das pernas na adolescência, as histórias do avô Adjiru, a permanência na missão católica e os constantes acessos psicopatológicos são as principais substâncias dos escritos. Também Baleiro se utiliza da escrita como meio para examinar o seu passado. A enfermidade mental do irmão, a paixão reprimida pela cunhada, Luzilia, e a morte do pai pelas mãos do irmão doente são elementos que carreiam o diário do caçador.

As divagações de ambos os narradores convergem em um tema comum ao utilizarem a escrita como forma mediadora entre suas pulsões íntimas e o mundo: o humano frente à morte e à insanidade. Na produção de Mia Couto, em geral, a morte é um episódio tratado com naturalidade, sem lugar especial à tristeza. Não obstante, aparece ao lado da loucura em A confissão da Leoa. Os escritos de Baleiro explicam que o morto ainda é parte integrante da vida social, continua a interferir nas regras dos vivos. Já a loucura, para o caçador, é a alienação plena e a verdadeira morte do sujeito social. No caso de Mariamar, a relação entre vida social e morte ganha outros sentidos. A moça vê a si mesma como alguém que nunca nasceu. Nascida já morta, desumanizada 
e desencontrada do meio social, persegue a sua própria humanidade reincidentemente negada por todos.

A condição de nascida morta não é exclusiva da protagonista. Constrói-se no romance o apagamento da existência feminina: a mulher, seja na realidade tradicional ou no contexto do assimilado, sofre a subjugação por meio da exploração, da agressão física e psíquica e da anulação do direito à voz. A mãe de Arcanjo Baleiro é submetida a kusungabanga, isto é, costuram "a vagina da mulher com agulha e faca" (p. 203) antes da emigração do marido para trabalhar. A narradora e suas irmãs são abusadas sexualmente pelo pai. Tandi, empregada do administrador da província, é violentada e morta pelos homens da aldeia por cruzar uma região proibida às mulheres. Todas são impedidas de frequentar a shitala, local de encontro dos homens na comunidade. Contudo, a primeira dama da província, Naftalinda, aparece então como a voz que confrontará esta realidade, denunciando em alto tom o crime cometido pelos homens e demonstrando publicamente que se opõe às regras de submissão impostas à mulher.

Já no caso da morte, esta possui um lugar significativo na memória das personagens. Os habitantes de Kulumani, ao serem interrogados sobre os eventos da guerra, mantinham silêncio. Arcanjo Baleiro esclarece o mutismo: “Onde há sangue não há palavra. O escritor [Gustavo Regalo] está a pedir aos mortos que mostrem as cicatrizes" (p. 109). Todas as personagens do romance, tanto as originárias da aldeia como as da cidade, possuem a cicatriz comum da colonização e da guerra em suas memórias.

A morte, entretanto, na cosmovisão africana, pressupõe também o renascimento dentro do ciclo natural. Mariamar, que nunca nascera e que fora despojada de sua humanidade, recebe de sua mãe, Hanifa Assulua, a corda do tempo que até então lhe negaram. As mulheres da família contam os meses de gravidez dando nós no antigo artefato. À Mariamar é dada a sua condição divina no desfecho da narrativa. É detentora da criação da vida e do tempo. Talvez seja esta a razão da identidade de Deus ser concedida à mulher na introdução do romance.

COUTO, Mia. A Confissão da Leoa. São Paulo: Companhia das Letras, 2012. 